\title{
Study on the Microscopic Fracture Process and Acoustic Emission of Shale Based on Digital Image
}

\author{
Motian Tang, ${ }^{1}$ Zhonghu Wu $\mathbb{D}^{1,2,3}$ Anli Wang, ${ }^{4}$ Yujun Zuo ${ }^{1},{ }^{5}$ Yili Lou, ${ }^{1}$ Hao Liu, ${ }^{5}$ \\ and Wenjibin Sun ${ }^{5}$ \\ ${ }^{1}$ College of Civil Engineering, Guizhou University, Guiyang 550025, China \\ ${ }^{2}$ School of Qilu Transportation, Shandong University, Jinan 250002, China \\ ${ }^{3}$ Geotechnical and Structural Engineering Research Center, Shandong University, Jinan 250061, China \\ ${ }^{4}$ Guizhou Province Quality and Safety Traffic Engineering Monitoring and Inspection Center CO., LTD, Guiyang 550025, China \\ ${ }^{5}$ Mining College, Guizhou University, Guiyang, Guizhou 550025, China
}

Correspondence should be addressed to Zhonghu Wu; wuzhonghugzu@163.com

Received 10 September 2020; Revised 23 November 2020; Accepted 22 December 2020; Published 18 January 2021

Academic Editor: Yixian Wang

Copyright (c) 2021 Motian Tang et al. This is an open access article distributed under the Creative Commons Attribution License, which permits unrestricted use, distribution, and reproduction in any medium, provided the original work is properly cited.

\begin{abstract}
The Niutitang Formation shale is often filled with calcite minerals, which significantly affects the physical and mechanical properties of shale reservoirs. To correctly understand the microscale fracture characteristics of the Niutitang Formation shale and the evolution of acoustic emission signals, this paper uses digital image processing technology to characterize the geometric characteristics and nonuniform distribution of calcite minerals in the shale at the microscale and then maps it to finite elements; uniaxial compression tests of different calcite vein inclination angles are carried out on a microscale. The results show that under the microscale structure, the changes in compressive strength and brittleness index of the Niutitang Formation shale with different calcite vein dip angles are all $\mathrm{N}$-shaped. The calcite veins affect the distribution of the stress field, leading to significant differences in the shale fracture process and fracture mode. The shale fracture process can be divided into two types. The first type $\left(0^{\circ}, 15^{\circ}, 30^{\circ}, 45^{\circ}\right)$ is that the shale matrix is destroyed first, and then, the calcite veins are destroyed; the second type $\left(60^{\circ}\right.$, $\left.75^{\circ}, 90^{\circ}\right)$ is that the calcite veins are destroyed first, and then, the shale matrix is destroyed. Shale fracture modes can be divided into w-type, v-type, inverted v-type, and inverted z-type. The inclination angle of calcite veins has a significant influence on the AE evolution characteristics of the Niutitang Formation shale. According to the characteristics of the AE active period, it can be divided into two types: surge type and step type. The surge type has a short active period, the number of AE count surges is small, the AE peak is large, and the failure mode is relatively simple. The step type has a long active period, the number of AE count surges is large, and the AE peak is small, and the failure mode is relatively complicated. The research results provide important theoretical guidance for shale gas fracturing mining.
\end{abstract}

\section{Introduction}

With the consumption of conventional oil and gas resources such as petroleum, shale gas has become the frontier field of oil and gas exploration and development today $[1,2]$. In recent years, substantial progress has been made in the development of shale gas in China, and shale gas is expected to become an alternative energy source for conventional oil and gas resources [3-5]. As long as it can break through to form large-scale production capacity, it will certainly alleviate China's oil and gas resource tensions and have important economic value and strategic significance to China [6]. The Lower Cambrian Niutitang Formation shales in northern Guizhou are widely distributed, with high content of brittle minerals such as quartz and calcite, and complex mineral composition and pore structure $[7,8]$. It is a favorable reservoir for marine shale gas exploration, but the problems of low porosity and low permeability and severe heterogeneity are common in the shale reservoir, which is not conducive to the development of shale gas $[9,10]$. In addition, during the deposition process of black shale, the preferred orientation of mineral crystalline particles results in the shale having 
obvious stratification and bedding structure, which has anisotropic effects on the strength and brittleness of shale, causing various problems in shale gas exploitation. At present, the development of shale gas in China is still in its infancy, mainly using artificial fracturing to form a more complex fracture network system for the development of shale gas [11]. Therefore, conducting mechanical test research on the Niutitang Formation shale to understand its shale mechanical characteristics, fracture process, and acoustic emission characteristics can provide effective parameters for shale gas reservoir drilling, construction, and fracturing effect evaluation.

Scholars at home and abroad have done a lot of research on the anisotropy of shale mechanical and failure characteristics. Niandou [12] studied the anisotropy of shale mechanical behavior through hydrostatic compressibility test and triaxial compression test and pointed out that the anisotropy of shale is mainly related to confining pressure and loading direction. Wenk et al. [13] studied the shale geomechanical characteristics through laboratory experiments and measured the relationship between ultrasonic velocity and pressure and direction by using a triaxial loading device and $\mathrm{X}$ ray diffraction technology and then compared the results of mineralogy, structure, and seismic wave analysis. The results show that shale is a good candidate for storing radioactive waste. Cheng et al. [14] conducted uniaxial and triaxial compression tests on the dry and water-saturated samples of coal to measure shale and studied the effects of anisotropy and water content on shale strength and deformation behavior. Geng et al. [15] conducted triaxial compression tests on shale at different angles and different confining pressures. The results show that at a certain bedding angle, the brittleness of the sample does not decrease with increasing confining pressure but increases with confining pressure. Wu et al. [16] carried out uniaxial compression numerical simulation experiments on the Niutitang Formation shale based on digital image processing at different angles. The fractal dimension was used to analyze the failure mode. The larger the fractal dimension, the more complex the failure mode. Wang et al. [17] conducted a Brazilian split test with different bedding angles on shale. Based on the transverse isotropy theory, the tensile stress at the center of the disk was obtained, and then, the evolution process and energy release characteristics of acoustic emission were analyzed. It is considered that the acoustic emission characteristics also reflect the anisotropic splitting behavior, and the influence of the bedding effect on the crack initiation and propagation acoustic emission characteristics is discussed. Zhang et al. [18] carried out the Brazilian split test, acoustic emission test, and 3DEC numerical simulation at different bedding angles on the Longmaxi Shale and believe that the AR curve can be divided into two modes: "gradual-steep increase" type and step type. Heng et al. [19] conducted a direct shear test on shale at different bedding angles, and the results showed that the shear parameters such as shale strength, cohesion, and internal friction angle reached maximum and minimum values at $60^{\circ}$ and $0^{\circ}$, respectively. Wang et al. [20] first conducted a direct shear test on the layered rock and then conducted a numerical shear test on the stratified rock model and the discrete fracture network (DFN) model. The results show that the peak shear stress is more sensitive to dip angle than normal stress, and stratified rock has obvious shear anisotropy and directionality. The development of shale gas in China started late, and most of the researches are limited to the macroscopic failure modes and mechanical characteristics, and there is insufficient research on the inhomogeneity and anisotropic failure mechanism of shale materials at the microscale. The study of the microscopic mechanism of shale fracture is of great significance to the prediction of crack propagation and the development of shale gas. Therefore, it is necessary to study the microscale anisotropy of shale.

In this paper, polarized light microscope is used to observe the internal microstructure of Niutitang Formation shale, and digital image processing technology is used to characterize the geometric characteristics and nonuniform distribution of calcite minerals under the shale microscale. The Niutitang Formation shale is subjected to uniaxial compression numerical experiments with different calcite vein inclination angles at the microscale. The mechanical properties and crack evolution mechanism of the Niutitang Formation shale at the microscale are studied, and the acoustic emission evolution law is analyzed. The results reveal the microfracture mechanism of the shale in the Niutitang Formation in northern Guizhou and will provide theoretical support for the exploitation of shale gas in the northern Guizhou area.

\section{Geological Background}

The study area of the Fenggang No.3 block is located in the northern part of Guizhou. The administrative division is under the jurisdiction of Meitan County, Fenggang County, and Sinan County in the southeast of Zunyi District, Guizhou Province, covering an area of $1167 \mathrm{~km}^{2}$. In the division of regional tectonic units, the Fenggang No.3 block belongs to the Yangtze plate, the northern plateau uplift in Guizhou, and the north-north-eastward tectonic deformation zone of Fenggang. The structure of the study area is well-developed, and the directions are mainly NNE, NE, and NS. The tectonic forms are mainly folds and faults, and the geological structural conditions are complicated [21]. The study area underwent multiple superimposed transformations of the snow mountain movement, early middle Caledonian movement, late Caledonian movement, Hercynian movement, IndoChinese movement, Yanshan movement, and Himalayan movement, which established the present complex geological tectonic pattern. Among them, the Yanshan tectonic movement is the most important period of fault formation in Fenggang area. The fault zones formed during the Yanshan tectonic movement were mainly torsional faults, and the folds were mainly "grooved" structures. A series of northeastward complex anticlines and complex synclines have been developed. The strong tectonic movement not only caused complex changes in geology but also caused the widespread development of shale fractures. Fractures in the Niutitang Formation were filled by minerals such as calcite and pyrite during the process of tectonic evolution [22]. According to the filling characteristics, the fractures in the Niutitang 

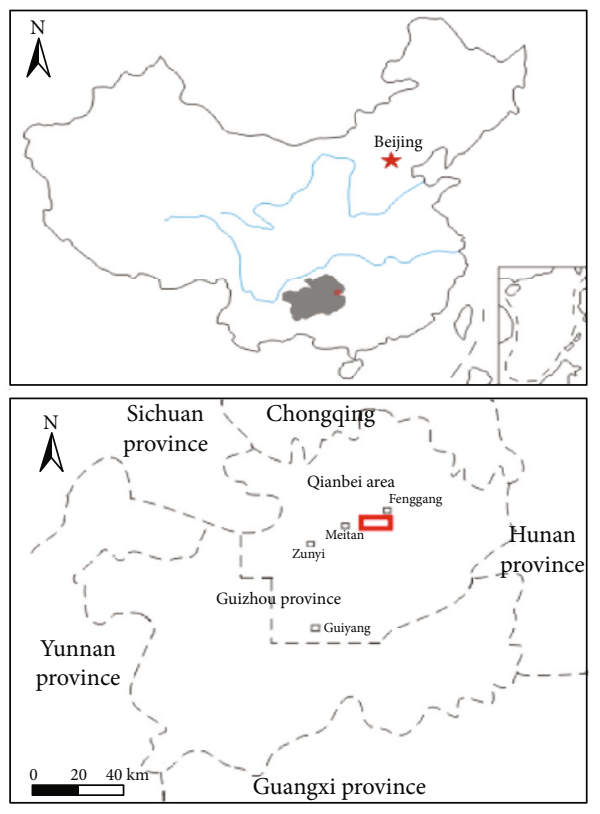

$\square$ Work area

$\square$ Place name

- Provincial boundaries

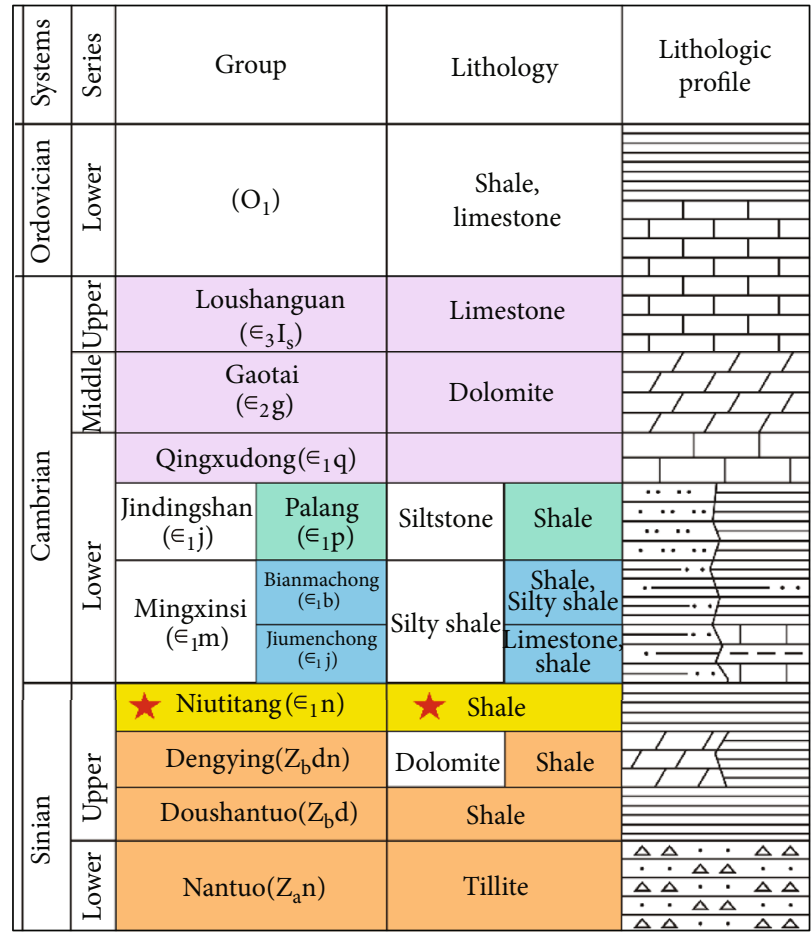

Figure 1: Geographic location of the study area and histogram of lithology [22].
Formation can be divided into two types: calcite filling and organic filling. The calcite filling cracks of Niutitang Formation are relatively well developed, which can be seen in the field underground core and under the microscope [23]. Crack filling has an impact on the shear resistance and strength of the rock [24].

The stratigraphic development of the study area is shown in Figure 1. The Fenggang No.3 Block is an area rich in oil and gas resources and is one of the national shale gas pilot test areas. The shale gas resource has great potential, and the Lower Cambrian Niutitang Formation is one of the target strata with the most exploration and development potential. Marine sediments are widely developed in the study area in Guizhou. The Cambrian shale developed in the Niutitang Formation, with shale thickness ranging from 80 to $110 \mathrm{~m}$, mainly siliceous shale and gray-black shale. The study area has a high organic carbon content (TOC) of 3.54\%-8.12\%, the average TOC content is $7.24 \mathrm{wt} \%$, and the maturity of organic matter is large, and the value is generally between $2.0 \%$ and $4.0 \%$. The Lower Cambrian Niutitang Formation in Guizhou has good development potential [21].

\section{Methodology}

3.1. Basic Principles. RFPA2D is based on the damage mechanics constitutive relationship and uses the finite element method to carry out stress analysis and damage analysis on the rock. When the crack propagates in the finite element model, the element has been defined as partial failure but has not been removed in the calculation. Because rock materials are brittle materials, RFPA2D uses Mohr-Coulomb strength theory with tensile criterion to simulate the entire failure process. The element satisfies the constitutive relationship of shear failure and tensile failure under uniaxial stress. Initially, the element is defined as elastic, and its elasticity is defined by the elastic modulus and Poisson's ratio. Before reaching the damage threshold, consider the element's stress-strain state as linear elastic and then modify it by softening. The characteristics of the element are described based on the constitutive law of continuous damage mechanics $[25,26]$. The elastic model of the model decreases with the accumulation of damage. The elastic modulus of the damaged material is defined as follows:

$$
E=(1-D) E_{0} .
$$

In the formula, $E$ and $E_{0}$ are the elastic modulus of the damaged material and initial elastic modulus, and $D$ is the damage variable. When the stress or strain of the element reaches a given damage threshold (tensile criterion and Mohr-Coulomb criterion), the element begins to be damaged.

Under uniaxial tensile stress, the constitutive relationship of the element elastic damage is shown in Figure 2. When the elementary tensile stress reaches uniaxial tensile strength,

$$
\sigma_{3}<-\sigma_{t}
$$




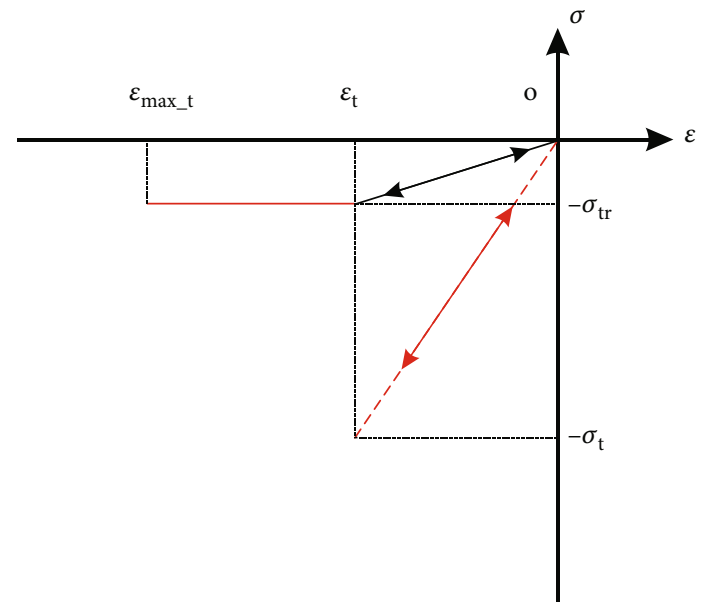

FIGURE 2: Elastic damage constitutive law of element under uniaxial tensile stress.

In the formula, $\sigma_{t}$ is the tensile strength of the element. The formula of the element damage variable $D$ under uniaxial tensile stress is:

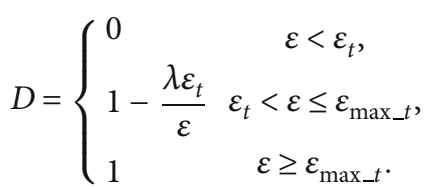

In the formula, $\lambda$ is the residual strength coefficient. This article assumes that the residual strength coefficient $\lambda=\sigma_{\text {tr }} / \sigma_{t}=0.1 . \varepsilon_{t}$ is expressed as the maximum tensile strain, which refers to the amount of ultimate tensile strain in the elastic state. $\varepsilon_{\text {max } \_t}$ is the ultimate tensile strain, which refers to the strain value at which the element is about to lose its bearing capacity.

Under uniaxial compression stress, the elastic constitutive relationship of this element is shown in Figure 3. When the element is subjected to shear stress, the Mohr-Coulomb criterion expression is selected to define the second damage threshold,

$$
\sigma_{1}-\frac{1+\sin \theta}{1-\sin \theta} \sigma_{3} \geq \sigma_{c}
$$

In the formula, $\sigma_{1}$ and $\sigma_{3}$ are the large principal stress and the small principal stress, respectively, $\sigma_{c}$ is the uniaxial compressive strength of the element, and $\theta$ is the friction angle. The element damage variable $D$ in the uniaxial state can be expressed as:

$$
D= \begin{cases}0 & \varepsilon<\varepsilon_{c}, \\ 1-\frac{\lambda \varepsilon_{c}}{\varepsilon} & \varepsilon \geq \varepsilon_{c} .\end{cases}
$$

In the formula, $\varepsilon_{c}$ is the maximum compressive strain, which refers to the ultimate compressive strain in the elastic state. $\lambda$ is the residual strength coefficient.

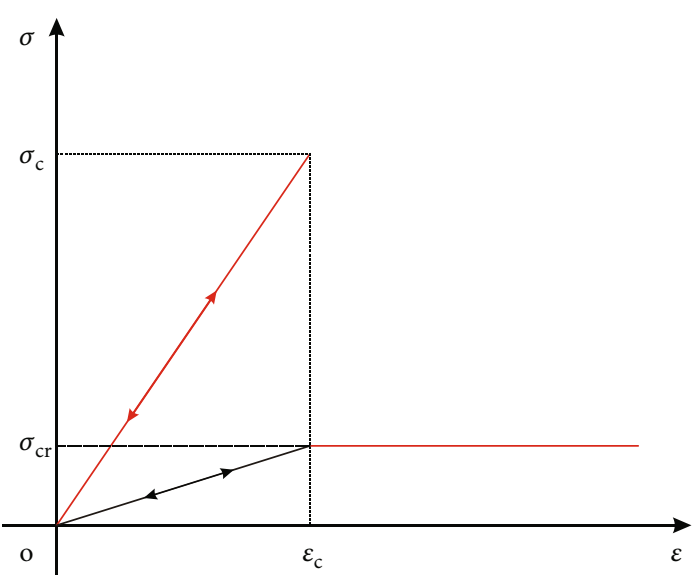

FIgURe 3: Elastic damage constitutive law of element under uniaxial compression stress.

3.2. Digital Image Acquisition and Characterization. The shale sample was taken from Well FC-1 in the northern part of Guizhou Province, with a sampling depth of 2490 2503 m, belonging to the Lower Cambrian Niutitang Formation. The shale sample is black, and the fractures are filled with calcite. The author grinds the rock specimen into thin slices and observes the structural features at the microscopic level using a polarizing microscope (model ZEISS Scope.A1). The obtained Niutitang Formation shale microscopic slice image is used as the test object (Figure 4). The resolution of the image is clear, in which the black shale matrix is filled with calcite veins and mineral particles. In this paper, digital image technology is used to characterize the nonuniform distribution of calcite minerals and quartz minerals in shale. According to the optical characteristics of the minerals, the mechanical properties are mapped to different finite element grids to establish a finite element model. HIS color space is based on the human visual system, using $H$ value (Hue), $S$ value (Saturation), and $I$ value (Intensity) to describe colors. According to the color characteristics of shale, it can be seen that the color of the image is relatively close to the black-gray image. Therefore, this paper adopts the threshold segmentation method, and the $I$ value (Intensity) in the HSI color space is used for threshold segmentation [27, 28]. The red scan line $\mathrm{AA}^{\prime}$ passes through the position of the mineral medium in the shale microscopic image, and the obtained $I$ value change curve is shown in Figure 5, and the range of $I$ is 0 to 255 . When the scan line $\mathrm{AA}^{\prime}$ passes through the calcite mineral from the shale matrix, the $I$ value increases significantly. When the scan line $\mathrm{AA}^{\prime}$ passes through the quartz minerals from the shale matrix, the $I$ value increases slightly. When the scan line $\mathrm{AA}^{\prime}$ passes from the calcite mineral to the quartz mineral, the $I$ value decreases slightly. By comparing the changes of the mineral composition and the $I$ value in the scanning area, the optimal threshold value is 60 and 140 after multiple value comparisons. The threshold divides the value of $I$ into intervals of 0 to 60,60 to 140 , and 140 to 255 , that is, the internal medium of the shale sample is divided into shale matrix ( 0 to 60 ), quartz minerals (60 140), and calcite minerals (140 255). Figure 6 shows 


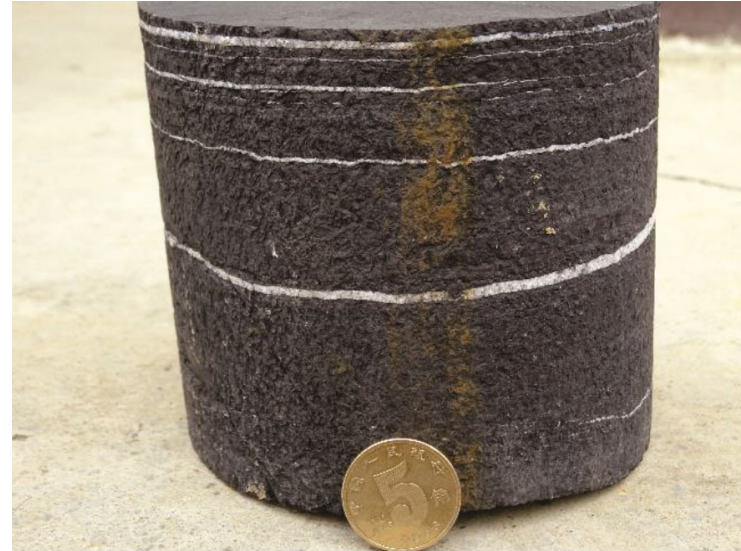

(a)

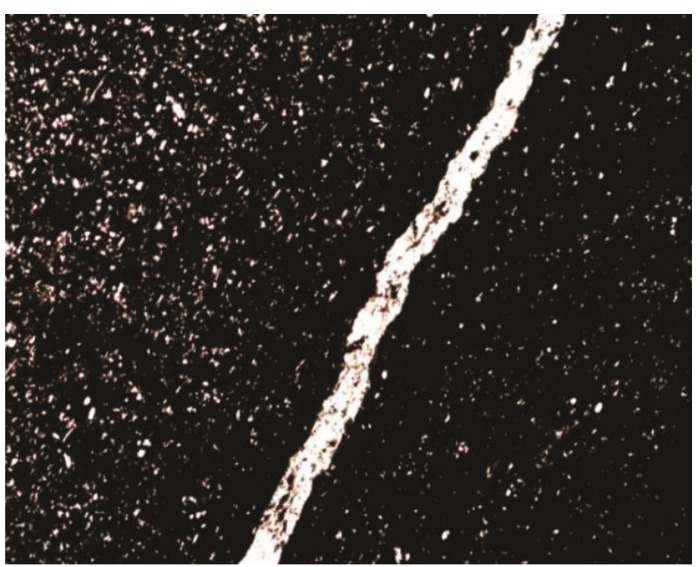

(b)

FIGURE 4: Image of calcite veins in shale: (a) macrostructure; (b) microstructure.

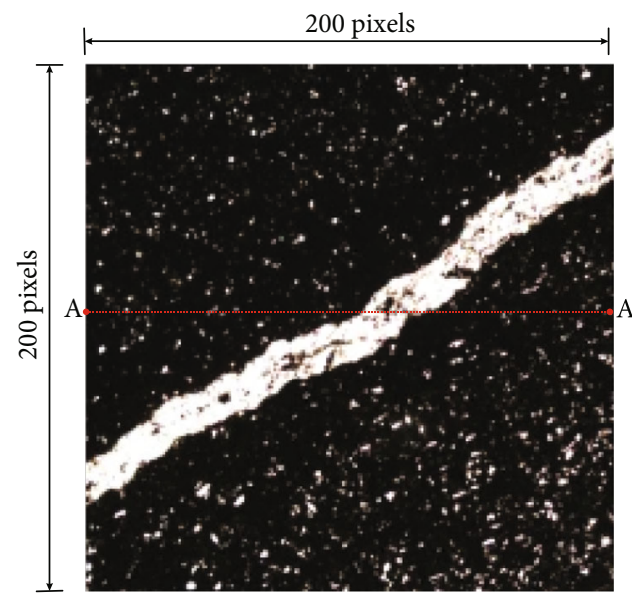

(a)

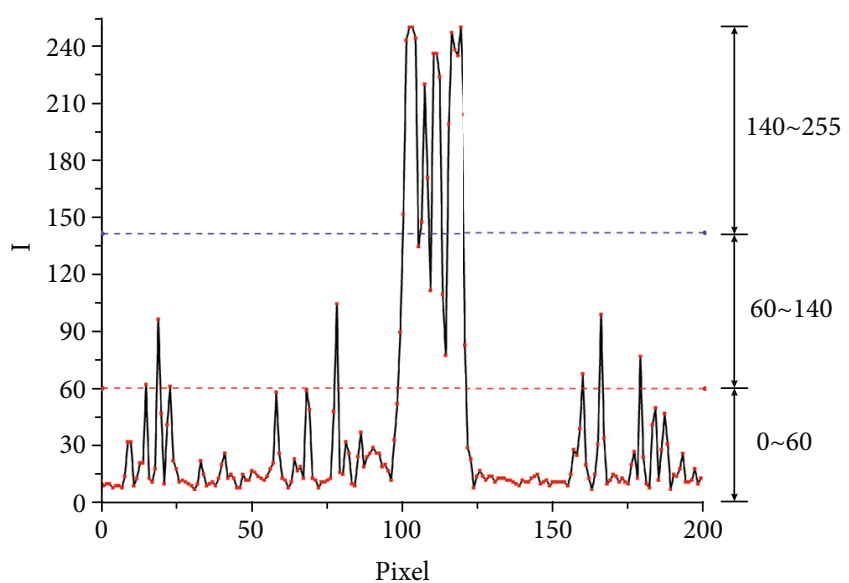

(b)

Figure 5: Threshold segmentation process: (a) positon of scan line $\mathrm{AA}^{\prime}$; (b) trend of $I$ value.

the image after threshold segmentation. Red represents calcite minerals, green represents quartz minerals, and blue represents shale matrix. Digital image processing technology accurately reflects the geometric characteristics and nonuniform distribution of calcite minerals in shale.

The shale sample has developed nano-scale pores and complex mineral composition $[29,30]$. In order to consider the heterogeneity of the rock, it is assumed that the mechanical properties of the primitive obey the Weibull statistical distribution:

$$
\phi(\alpha)=\frac{m}{\alpha_{0}} \cdot\left(\frac{\alpha}{\alpha_{0}}\right)^{m-1} \cdot e^{-\left(\frac{\alpha}{\alpha_{0}}\right)^{m}}
$$

In the formula, $\alpha$ represents the mechanical property parameters of the element, such as elastic modulus and compressive strength. $\alpha_{0}$ is related to the average value of the mechanical properties of the element. $m$ represents the homogeneity of the material. The greater the homogeneity $m$, the more uniform the material, and the mechanical properties of the elements will be concentrated in a narrow range.

3.3. Establishment of Numerical Model. A digital image is composed of a large number of rectangular pixels, and each pixel can be used as a quadrilateral element of the finite element grid. In the combination of finite element calculation and digital image processing technology, image analysis is performed before the microstructure is extracted. According to the color of mineral particles, image processing software is used to distinguish various mineral particles. After importing RFPA2D, according to the image size of 200 pixels $\times 200$ pixels, the digital image is divided into $200 \times 200$ finite element grids. For each pixel, the coordinates of the four corner points can be converted into the corresponding physical position in the vector space [31]. The node coordinates can be obtained by transforming the actual size of the image and the pixel size of the image, and the conversion method 


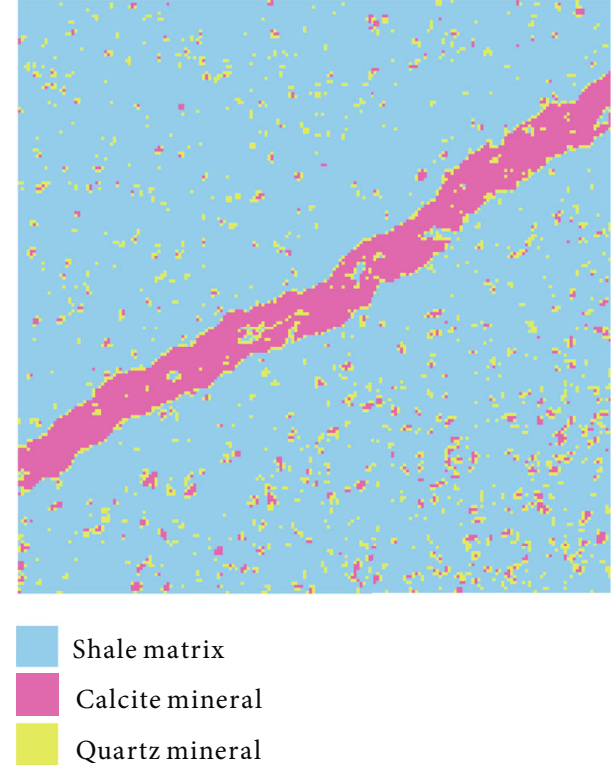

FIGURE 6: Shale heterogeneity characterization image.

is shown in Figure 7. Assume that the pixels with $I$ values in the range of 0 to 60 are shale matrix, the pixels with $I$ values in the range of 60 to 140 are quartz minerals, and the pixels with $I$ values in the range of 140 to 255 are calcite minerals. They have specific mechanical properties such as elastic modulus and compressive strength. According to the color category of each pixel, the corresponding material type is assigned to consider the true nonuniformity of shale and the geometric characteristics of calcite minerals. It is assumed that the internal element mechanical properties of shale obey the Weibull statistical distribution, so as to consider the inhomogeneity of complex mineral composition and nano-scale pores in the shale. According to literature $[16,32,33]$, the mechanical parameters of the Niutitang Formation shale are shown in Table 1.

To study the anisotropy characteristics of shale at the microscale, the method of obtaining digital images of shale with different dip angles of calcite veins is described below. First, a circular frame with a diameter of 283 pixels is used as a tool to obtain a circular digital image containing calcite veins. Secondly, using the 200 pixels $\times 200$ pixels screenshot frame as a tool to obtain the digital image of the calcite vein angle $\alpha=0^{\circ}$; then, the fixed frame center is rotated by $15^{\circ}$ to obtain the digital images of the Niutitang Formation shale calcite vein angle $\alpha=15^{\circ}, 30^{\circ}, 45^{\circ}, 60^{\circ}, 75^{\circ}$, and $90^{\circ}$ to ensure that the internal structure of the numerical shale experiment is basically the same. This paper designs 7 sets of microscopic uniaxial compression numerical experiments with different calcite vein inclination angles. The calcite vein angle $\alpha$ is $0^{\circ}$, $15^{\circ}, 30^{\circ}, 45^{\circ}, 60^{\circ}, 75^{\circ}$, and $90^{\circ}$, and they are unevenly distributed with irregular mineral particles in the shale. The pixels of each group of models are 200 pixels $\times 200$ pixels, and the finite element mesh is $200 \times 200$. The displacement load per step $\Delta S=0.01 \mu \mathrm{m}$, the schematic diagram of the numerical test loading method is shown in Figure 8.

\section{Test Results and Discussion}

4.1. Mechanical Properties and Fracture Process. Figure 9 shows the stress-strain curves of shale samples under uniaxial compression at different inclination angles. The results show that the stress value of the Niutitang Formation shale at different dip angles goes through a linear growth stage, a weakening stage, and then a postpeak drop stage and finally stabilizes with the increase of strain $\varepsilon$. It can be seen from Figure 6 that the yield point at the prepeak stage is not obvious. During the postpeak stage of the fall, the number of drops after the peak of $0^{\circ}, 30^{\circ}, 75^{\circ}$, and $90^{\circ}$ is more, showing the characteristic of gradual release of energy, and the number of drops after the peak of $15^{\circ}, 45^{\circ}$, and $60^{\circ}$ is relatively small, showing the characteristics of sudden release of energy.

Figure 10 shows the compressive strength and elastic modulus curve of the Niutitang Formation shale at different angles. It can be seen that the compressive strength of the Niutitang Formation shale at different angles shows significant anisotropy. When the inclination angle $\alpha=0^{\circ} \sim 15^{\circ}$, the compressive strength of the Niutitang Formation shale increases. When $\alpha=15^{\circ}$, the compressive strength of the Niutitang Formation shale is the highest, which is $23.55 \mathrm{MPa}$. When the inclination angle $\alpha=15^{\circ} \sim 75^{\circ}$, the compressive strength decreases sharply. When $\alpha=75^{\circ}$, the compressive strength of the Niutitang Formation shale is the smallest, which is $21.84 \mathrm{MPa}$; but $\alpha=75^{\circ} \sim 90^{\circ}$, as the inclination angle increases, the compressive strength increases sharply. It shows an $\mathrm{N}$-shaped change trend, which is similar to the change trend of fractured rock compressive strength [34]. The Niutitang Formation shale at different angles exhibits significant anisotropy. With the increase of the dip angle, the elastic modulus of the Niutitang Formation shale shows an $\mathrm{N}$-type trend. When $\alpha=90^{\circ}$, the elastic modulus of shale is the smallest, which is $22.59 \mathrm{GPa}$; when $\alpha=45^{\circ}$, the elastic modulus is the largest, which is $23.15 \mathrm{GPa}$. In the range of $\alpha=0^{\circ} \sim 15^{\circ}$ and $30^{\circ} \sim 45^{\circ}$, the elastic modulus is increasing. When the inclination angle $\alpha=15^{\circ} \sim 30^{\circ}$ and $\alpha=45^{\circ} \sim 90^{\circ}$, as the inclination angle increases, the compressive strength of the Niutitang Formation shale decreases sharply. It shows an M-type trend.

Shale gas reservoirs require large-scale fracturing reforms to achieve industrial productivity. Shale brittleness plays an important role in the stability of wellbore walls and reservoir reconstruction during drilling [35-37]. It is an important index to evaluate the characteristics of shale gas reservoir and to select high-productivity shale gas reservoir. Chen et al. [38] proposed a brittleness index based on the whole process of stress-strain of rock mass, which accurately and reasonably describes the brittleness characteristics of rock mass; the expression is:

$$
B_{i}=B_{i 1}+B_{i 2}=\frac{\left(\sigma_{p}-\sigma_{i}\right) / \sigma_{p}}{\left(\varepsilon_{p}-\varepsilon_{i}\right) / \varepsilon_{p}}+\frac{\left(\sigma_{p}-\sigma_{r}\right) / \sigma_{p}}{\left(\varepsilon_{r}-\varepsilon_{p}\right) / \varepsilon_{p}} .
$$

In the formula, $B_{i 1}$ and $B_{i 2}$ are prepeak brittleness index and postpeak brittleness index, respectively; $\sigma_{p}, \sigma_{i}$, and $\sigma_{r}$ 


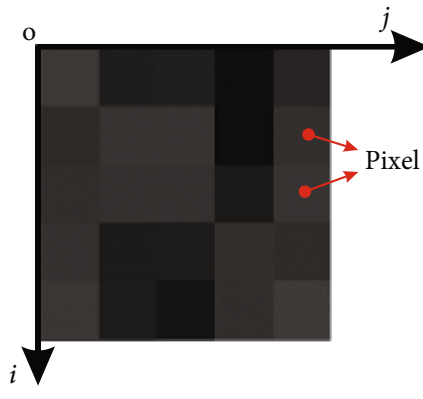

(a)

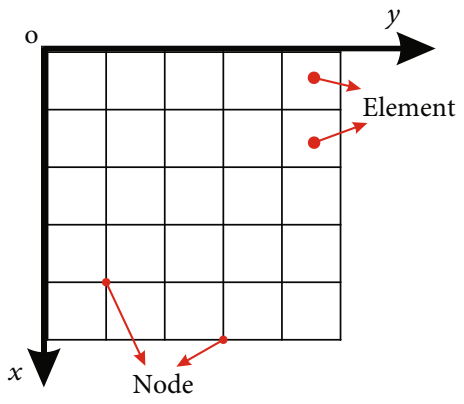

(b)

Figure 7: Conversion relationship of finite element mesh: (a) digital image pixels; (b) finite element mesh.

TABLE 1: Mechanical parameters of microdielectric materials.

\begin{tabular}{lcccccc}
\hline Materials & Homogeneity $m$ & Elasticity modulus $E / \mathrm{GPa}$ & ${\text { Compressive strength } \sigma_{c} / \mathrm{MPa}}$ & Poisson ratio $v_{v}$ & Frictional angle $\left(^{\circ}\right)$ & $\mathrm{C} / \mathrm{T}$ \\
\hline Shale matrix & 3 & 51.6 & 145 & 0.22 & 35 \\
Calcite mineral & 5 & 80.5 & 101 & 0.30 & 14 \\
Quartz mineral & 8 & 96 & 373 & 0.08 & 30 \\
\hline
\end{tabular}

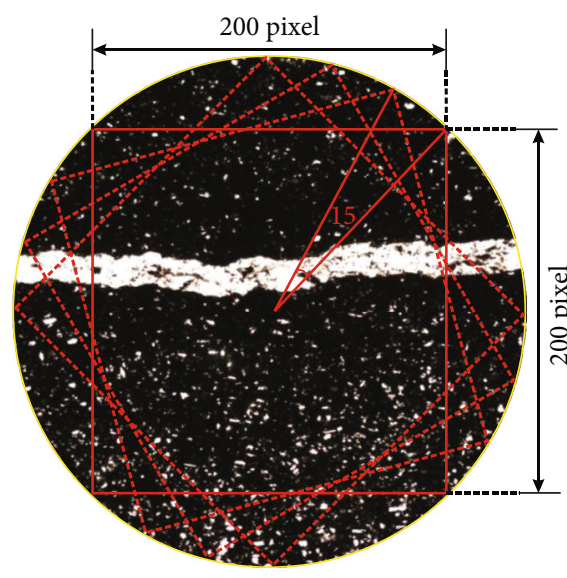

(a)

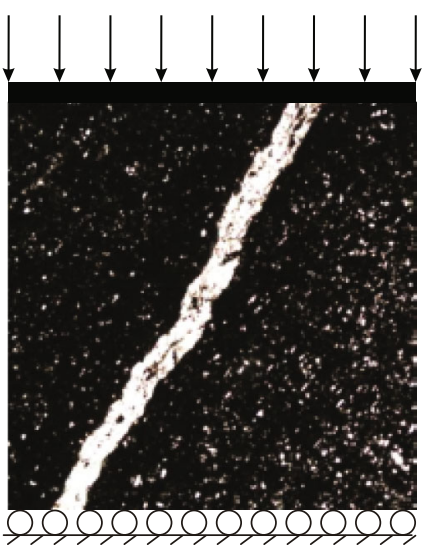

(b)

FIGURE 8: Numerical image acquisition and loading method: (a) method of obtaining; (b) loading method $\left(60^{\circ}\right.$ as an example).

are peak stress, cracking stress, and residual stress, respectively; $\varepsilon_{p}, \varepsilon_{i}$, and $\varepsilon_{r}$ are peak strain, cracking strain, and residual strain, respectively.

Table 2 shows the calculation results of the characteristic stress values, strain values, and brittleness indexes $B_{i 1}, B_{i 2}$, and $B_{i}$ during uniaxial compression. According to the calculation results in Table 2, a brittleness index change curve is made, as shown in Figure 11. The brittleness index of the Niutitang Formation shale at different inclination angles shows significant anisotropy. With the increase of the dip angle, the brittleness index of the Niutitang Formation shale increases first, then decreases, and then increases. The brittleness index and the compressive strength show a similar trend. When the inclination angle $\alpha=0^{\circ} \sim 15^{\circ}$, the brittleness index increases. When the inclination angle $\alpha=15^{\circ}$, the brittleness index reaches the maximum value, which is 2.34 . When the inclination angle $\alpha=15^{\circ} \sim 75^{\circ}$, the brittleness index began to decrease. When $\alpha=75^{\circ}$, the brittleness index showed a minimum value of 1.12; when the inclination angle $\alpha$ exceeded $75^{\circ}$, the brittleness index rebounded sharply and finally showed an N-type change trend.

Figure 12 shows the fracture process of the Niutitang Formation shale at different angles. It can be seen from Figure 12 that the failure mode of the Niutitang Formation shale is significantly affected by the inclination angle of calcite veins, and the failure modes at different inclination angles are different. According to the crack geometry, the failure modes of the Niutitang Formation shale with different inclination angles can be divided into 4 types:

(1) $w$-type $\left(0^{\circ}, 30^{\circ}\right)$. When $\alpha=0^{\circ}$, first two right diagonal cracks $f_{1}$ and $f_{2}$ will sprout in the lower middle part and the right edge of the bottom, respectively. The lower end of $f_{1}$ extends to the upper left, and the 


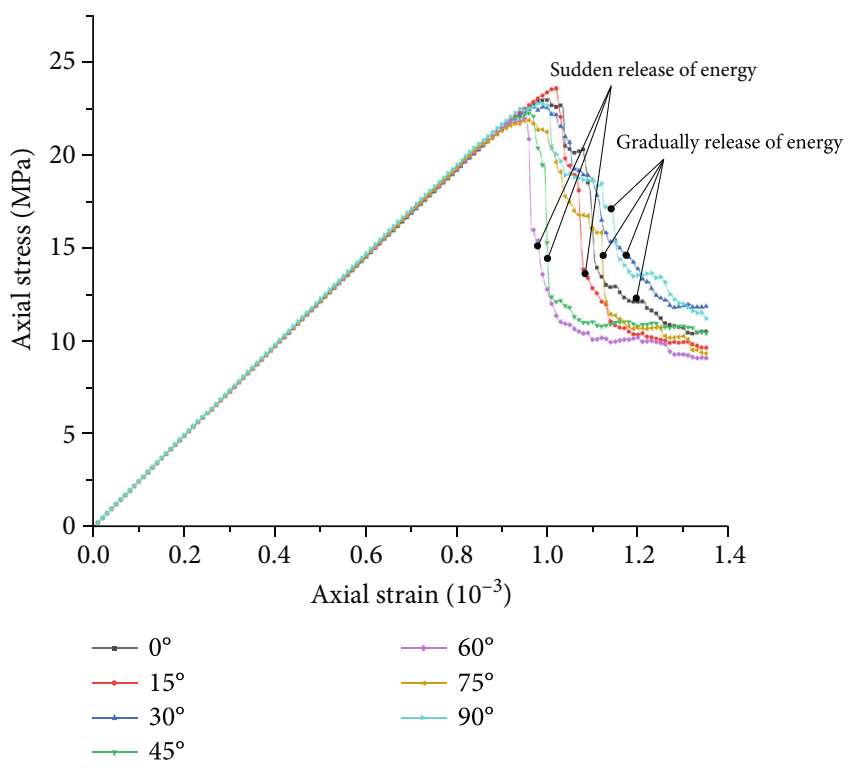

Figure 9: Stress-strain curves of the Niutitang Formation shale at different dip angles.

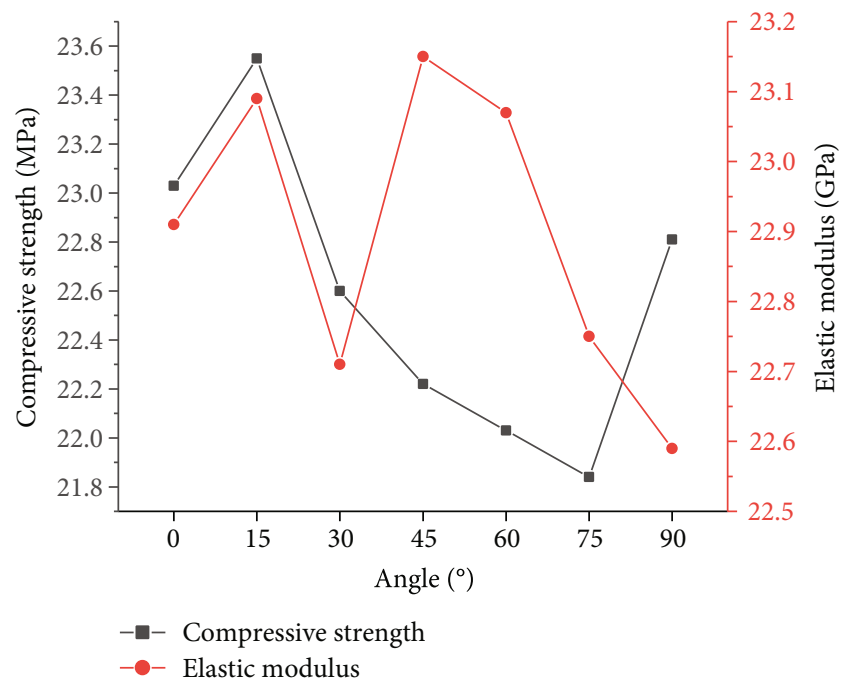

FIgURE 10: The compressive strength and elastic modulus curve.

upper end extends upwards. The bottom end of $f_{2}$ extends to the upper left and upper right and penetrates $f_{1}$ and the right side of the test piece, respectively. Eventually a w-shaped fracture mode is formed. When $\alpha=30^{\circ}$, firstly three left oblique cracks $f_{1}, f_{2}$, and $f_{3}$ sprang up in the lower middle, left bottom, and upper right part of the specimen, and then, three cracks extend to both ends. Among them, $f_{2}$ extends to the bottom edge and then extends to the upper right to penetrate through $f_{1}$, and $f_{3}$ extends to the right of the middle and extends to the upper right and lower left, respectively, and penetrates with the new crack in the upper right corner and $f_{1}$. Eventually, a w-shaped fracture mode is formed

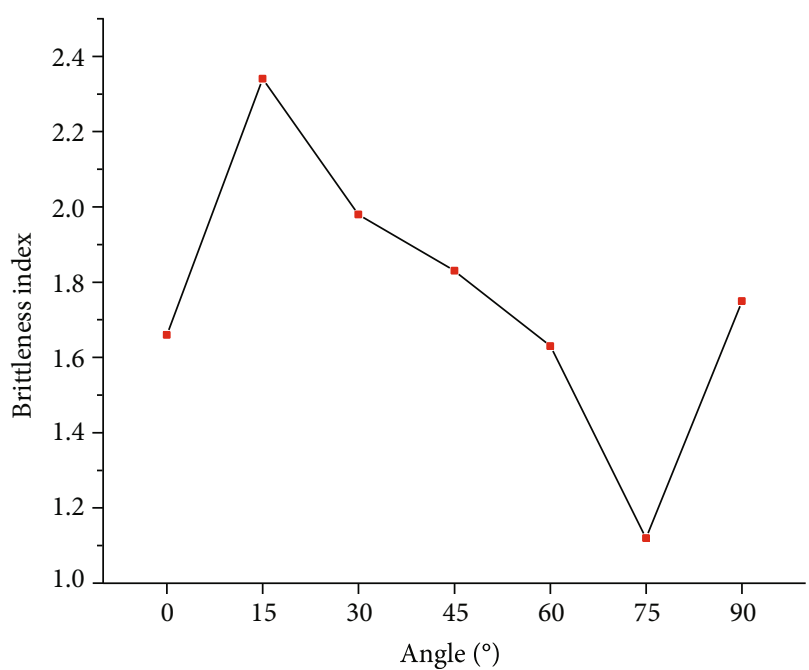

FIgURe 11: Brittleness index change curve.

(2) $V$-type $\left(15^{\circ}\right)$. When $\alpha=15^{\circ}$, first a right oblique crack $f_{1}$ sprouts in the middle of the right side of the specimen, and then, both ends of $f_{1}$ extended to the right and bottom edges. When $f_{1}$ reached the bottom edge, it began to extend to the upper left, and finally, a vshaped fracture pattern is formed

(3) Inverted v-type $\left(45^{\circ}, 60^{\circ}\right)$. When $\alpha=45^{\circ}$, a vertical crack $f_{1}$ sprouts at the top edge of the right side of the specimen first, and then, the bottom end of $f_{1}$ extends to the lower left and lower right, respectively. When $f_{1}$ extends to the lower left for a certain length, it starts to expand along the direction of calcite veins. Eventually, an inverted V-shaped fracture mode is formed. When $\alpha=60^{\circ}$, first two cracks $f_{1}$ and $f_{2}$ sprouted on the bottom left side of the specimen; the directions are left and right oblique, respectively. Then, $f_{1}$ and $f_{2}$ extend to both ends, and $f_{2}$ extends along the direction of the calcite veins to the top of the specimen and then extends to the right edge. Eventually, an inverted v-shaped fracture mode is formed

(4) Inverted $z$-type $\left(75^{\circ}, 90^{\circ}\right)$. When $\alpha=75^{\circ}$, first a left oblique crack $f_{1}$ sprouts on the top of the specimen, extending to the lower left (calcite vein direction) and lower right, respectively. $f_{1}$ extends from the lower left to the bottom edge and then starts to extend to the upper left and penetrates. At the same time, a right oblique crack sprouts from the upper right edge of the specimen and extends to the lower left and lower right to the right edge and penetrates through $f_{1}$. Eventually, an inverted z-shaped failure mode is formed. When $\alpha=90^{\circ}$, firstly, two right oblique cracks $f_{1}$ and $f_{2}$ sprout on the upper middle part and the top right side of the specimen and extend to both ends. $f_{1}$ extends along the direction of the calcite veins to both ends and starts to extend to the left when it reaches the lower part of the specimen. When 
TABLE 2: Uniaxial compression test data of the Niutitang shale at different angles.

\begin{tabular}{lccccccccc}
\hline$\alpha /\left(^{\circ}\right)$ & $\sigma_{i} / \mathrm{MPa}$ & $\varepsilon_{i} / 10^{-3}$ & $\sigma_{p} / \mathrm{MPa}$ & $\varepsilon_{p} / 10^{-3}$ & $\sigma_{r} / \mathrm{MPa}$ & $\varepsilon_{r} / 10^{-3}$ & $B_{i 1}$ & $B_{i 2}$ \\
\hline 0 & 22.69 & 0.97 & 23.03 & 1.00 & 10.39 & 1.47 & 0.49 & 1.17 \\
15 & 20.66 & 0.86 & 23.55 & 1.02 & 9.87 & 1.40 & 0.78 & 1.56 \\
30 & 21.73 & 0.92 & 22.60 & 0.99 & 11.75 & 1.32 & 0.54 & 1.44 \\
45 & 20.03 & 0.84 & 22.22 & 0.96 & 10.37 & 1.45 & 0.79 & 1.04 \\
60 & 21.50 & 0.91 & 22.03 & 0.95 & 8.82 & 1.49 & 0.57 & 1.05 \\
75 & 21.81 & 0.95 & 21.84 & 0.96 & 9.94 & 1.49 & 0.13 & 0.99 \\
90 & 22.33 & 0.97 & 22.81 & 1.01 & 9.81 & 1.48 & 0.53 & 1.63 \\
\hline
\end{tabular}

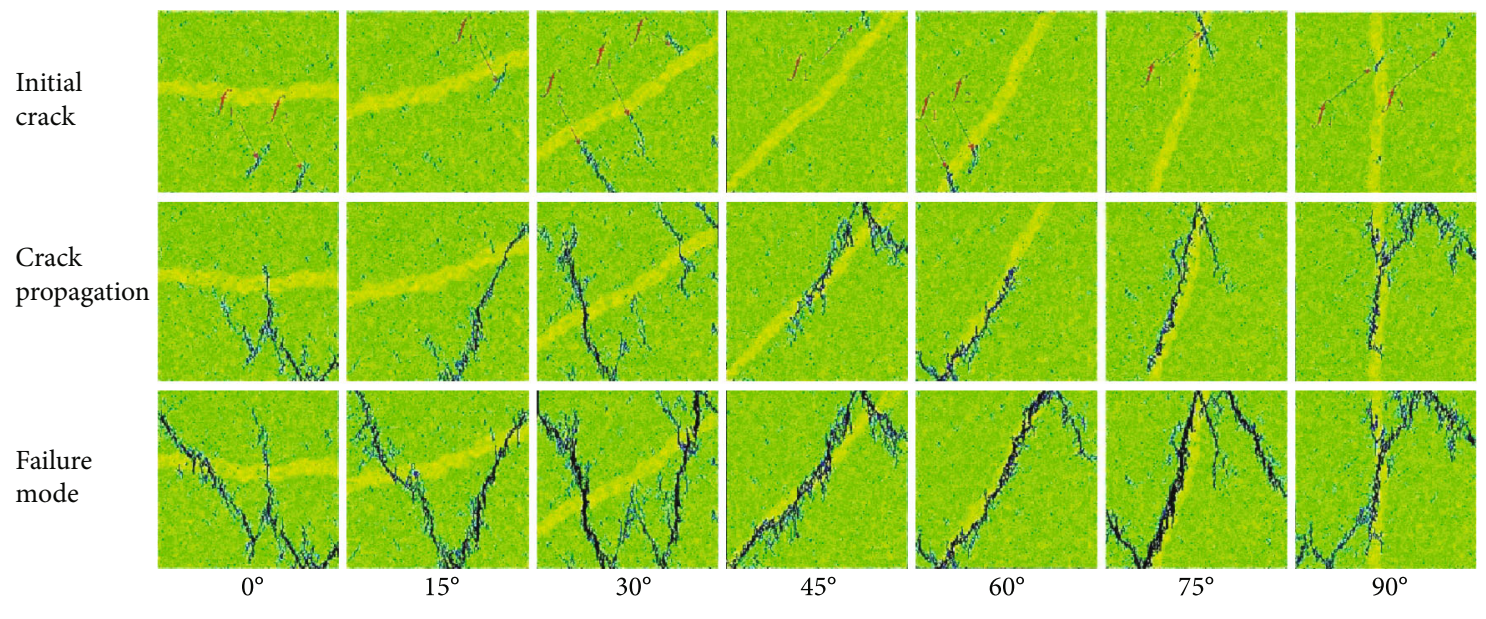

Figure 12: Fracture process of the Niutitang Formation shale at different angles.

$f_{1}$ reaches the bottom edge, it extends to the upper left. At the same time, $f_{2}$ is directed to the lower left and lower right rocks of the specimen, one end penetrates $f_{1}$, and the other end extends to the left edge of the specimen. Eventually, an inverted z-shaped failure mode is formed

According to the above analysis, the Niutitang shale failure modes with different dip angles can be divided into two types according to the failure sequence of shale matrix and calcite veins:

(5) The failure of calcite veins after the shale matrix $\left(0^{\circ}\right.$, $15^{\circ}, 30^{\circ}, 45^{\circ}$ ). When $\alpha=0^{\circ}, 15^{\circ}$, and $30^{\circ}$, the shale first forms cracks in the matrix, and finally, the cracks penetrate the calcite veins. When $\alpha=45^{\circ}$, the shale first formed cracks in the matrix and finally broke along the calcite veins

(6) The failure of the shale matrix after the calcite veins $\left(60^{\circ}, 75^{\circ}, 90^{\circ}\right)$. When $\alpha=60^{\circ}$ and $75^{\circ}$, the shale first forms cracks in the calcite veins; the cracks propagate along the calcite veins and then extend into the matrix. When $\alpha=90^{\circ}$, the shale first forms cracks in the calcite veins and then extends diagonally through the calcite veins into the matrix

According to the above analysis, the crack propagation mechanism is closely related to the calcite vein inclination angle. In the case of high angles $\left(60^{\circ}, 75^{\circ}, 90^{\circ}\right)$, the initial cracks initiate inside the calcite veins and appear to extend along the calcite veins. In the case of $\alpha=45^{\circ}$, the initial cracks are initiated in the shale matrix and extend along the calcite veins. In the case of low angles $\left(0^{\circ}, 15^{\circ}, 30^{\circ}\right)$, the initial cracks are initiated in the shale matrix and appear to cross calcite veins.

Stress concentration is the main reason for the initiation of microcracks due to local damage in the rock [39-42]. The strength and properties of the stress field determine the basic mode of crack propagation and penetration. Therefore, the stress field distribution is used to effectively analyze the crack propagation mechanism. Figure 13 is the distribution diagram of the maximum shear stress evolution, which truly demonstrates the whole process of the specimen's local stress-induced failure. It can be seen from Figure 13:

(7) During the crack incubation stage, with the increase of the calcite inclination angle, the shear stress intensity in the calcite vein changes from weak to strong. In the case of $\alpha=0^{\circ}, 15^{\circ}, 30^{\circ}$, and $45^{\circ}$, the shear stress distribution in the calcite veins is weak, but the shear stress distribution in the shale matrix region is relatively strong. At high angles $\left(\alpha=60^{\circ}, 75^{\circ}\right.$, and $\left.90^{\circ}\right)$, the shear stress distribution is strong in the calcite veins, and the shear stress distribution in the matrix region is relatively weak. Therefore, in the case of $\alpha=0^{\circ}, 15^{\circ}, 30^{\circ}$, and $45^{\circ}$, the initial cracks are first 


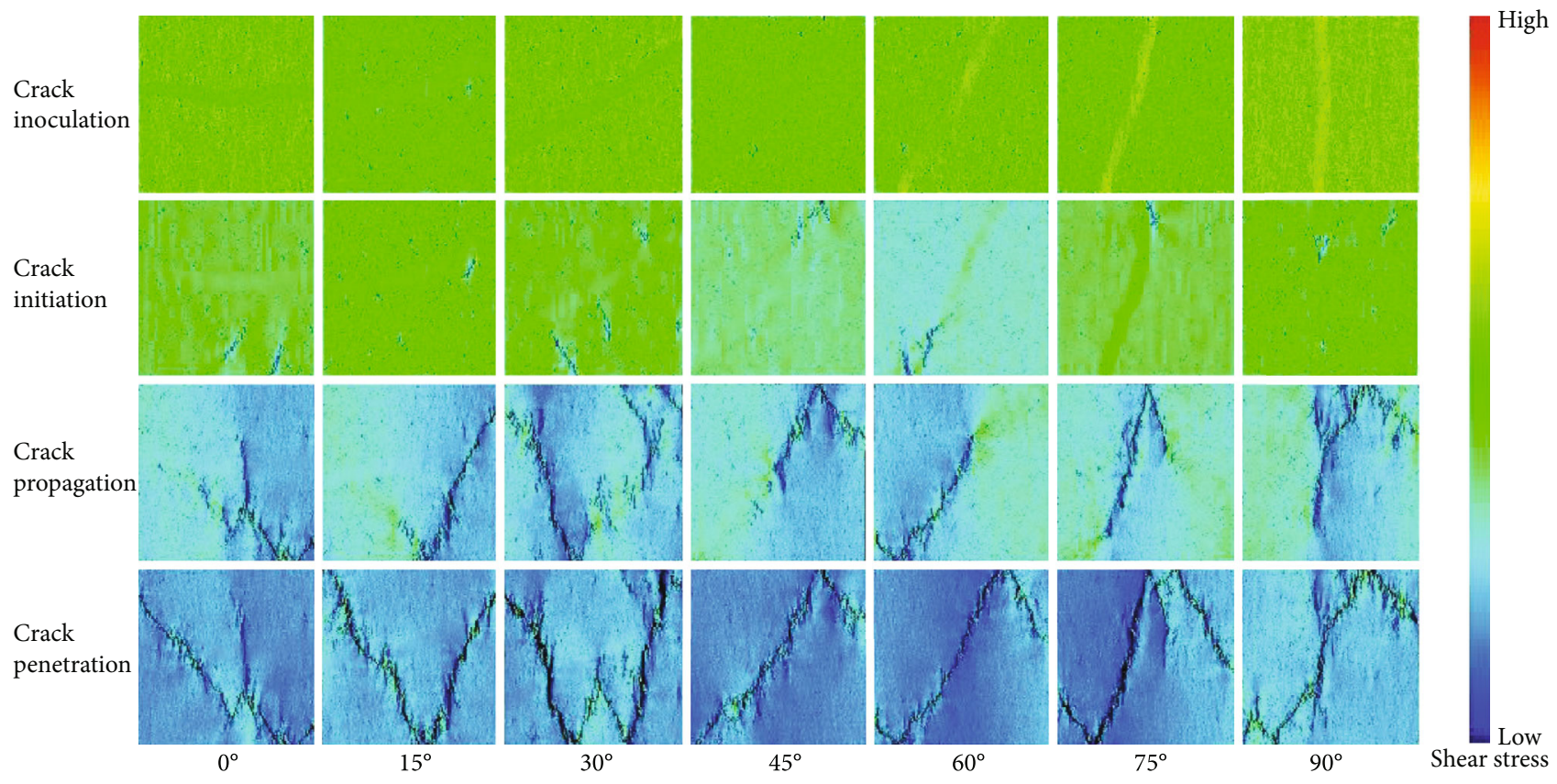

FIGURE 13: Shear stress distribution diagram.

initiated in the shale matrix. In the case of $\alpha=$ $60^{\circ}, 75^{\circ}$, and $90^{\circ}$, the initial cracks are first initiated in the calcite veins

(8) During the crack propagation stage, the internal structure of the rock changes the stress distribution in the specimen, which has a significant influence on the crack propagation. Stress concentration occurs at the crack tip, which easily induces the destruction of the crack tip element. In the area where the crack exists, the shear stress distribution intensity is relatively weak (blue), which causes the crack to expand to the area where the shear stress distribution intensity is stronger (green). As we all know, the strength of shear stress in the $45^{\circ}$ direction of the rock element is the largest. In the case of $\alpha=$ $45^{\circ}, 60^{\circ}, 75^{\circ}$, and $90^{\circ}$, the continuity of the contact surface between the calcite vein boundary and the shale matrix boundary and the mechanical properties of the calcite vein are poor. The initial cracks formed near the calcite veins are more likely to grow along the direction of the calcite veins under the action of shear force to form fracture surfaces. Therefore, in the case of $\alpha=0^{\circ}, 15^{\circ}$, and $30^{\circ}$, the crack finally appeared to cross calcite veins. In the case of $\alpha=$ $45^{\circ}, 60^{\circ}, 75^{\circ}$, and $90^{\circ}$, the final cracks all extend along the direction of the calcite veins

4.2. Evolution Characteristics of AE. After the RFPA system is simulated, it will automatically make an acoustic emission curve to analyze the failure process of the rock, which can be used as an effective means to predict rock failure. Because in the process of crack initiation and development, energy will be released instantaneously in the form of elastic waves, that is, acoustic emission signals are generated. Acoustic emission signals can continuously and real-time reflect the damage process inside the rock, record the time and space location of the damage occurrence, and can be used to study the dynamic evolution process of rock damage $[43,44]$. The release of elastic waves in the rock is directly related to the generation (damage) of the microcracks in the rock, and the acoustic emission mainly depends on the heterogeneity of the rock. Therefore, there is an inherent inevitable connection between the acoustic emission of the rock and the damage parameter and constitutive relationship of the rock. As an intuitive estimation, if the frequency and energy of each acoustic emission are not considered for the time being, the RFPA numerical simulation system assumes that the fracture of each rock element has a contribution to the acoustic emission. That is, the damage amount and acoustic emission of the rock are proportional to the number of damaged elements [26, 45]. Figure 14 shows the relationship between stress, current step acoustic emission count, cumulative acoustic emission count, and step count of the Niutitang Formation shale with different calcite vein dip angles. According to Figure 14, the stress-step curve is closely related to the AEstep curve. The stress-load step curve is roughly divided into 4 stages, namely, elastic stage, yielding stage, strengthening stage, and failure stage. The AE accumulative counts-load step curve is roughly divided into 3 stages, namely, the prepeak gentle stage, the growth stage, and the postpeak gentle phase. The AE counts-load step curve is roughly divided into silent phase, active phase, and postpeak gentle phase. According to the growth stage of the acoustic emission curve, the Niutitang Formation shale with different calcite dip angles is divided into two types.

(9) Surge type $\left(15^{\circ}, 45^{\circ}, 60^{\circ}\right)$. In the previous description, the stress-strain curve of $\alpha=15^{\circ}, 45^{\circ}$, and $60^{\circ}$ has a small number of drops, showing the 
Step type
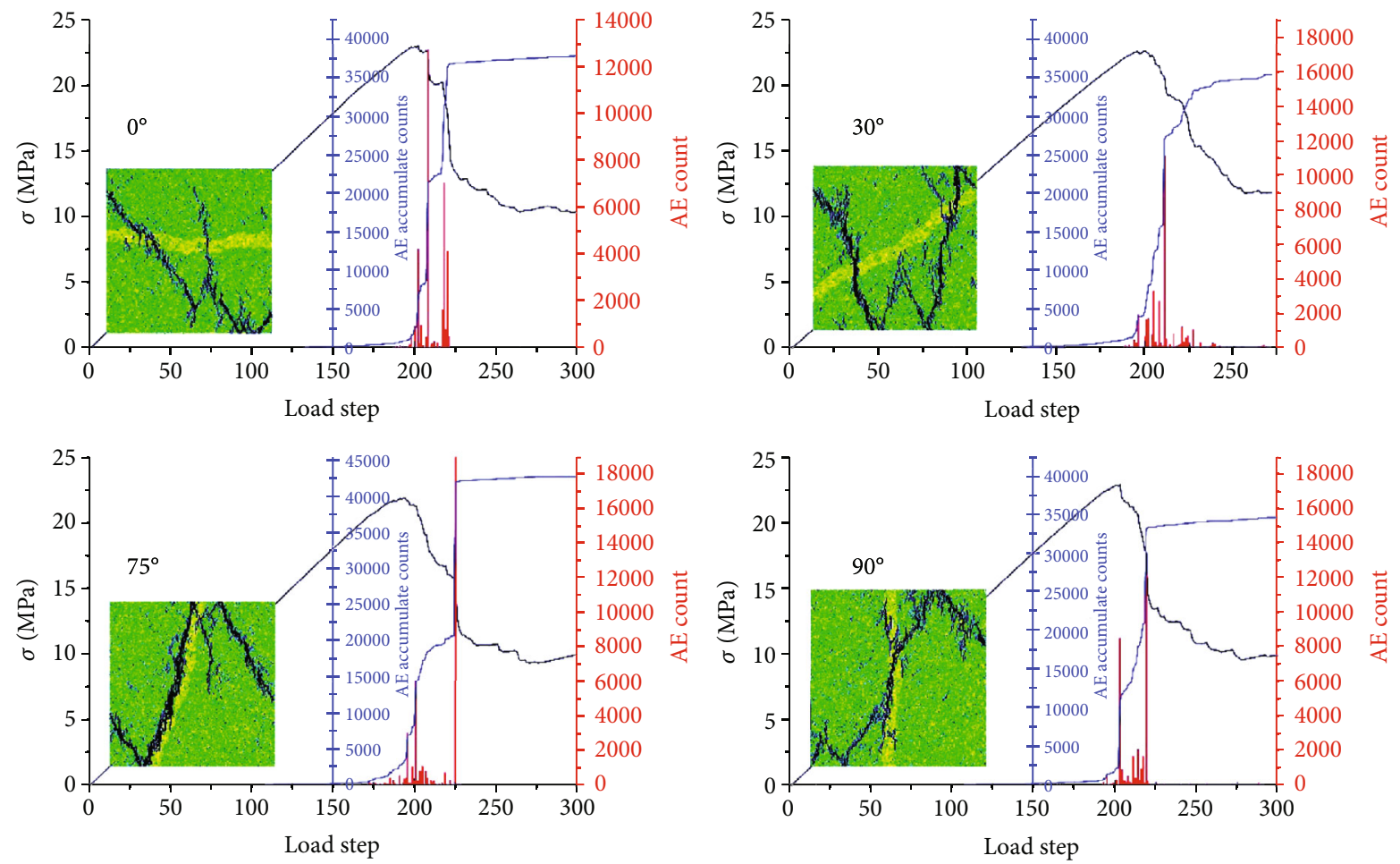

(a)
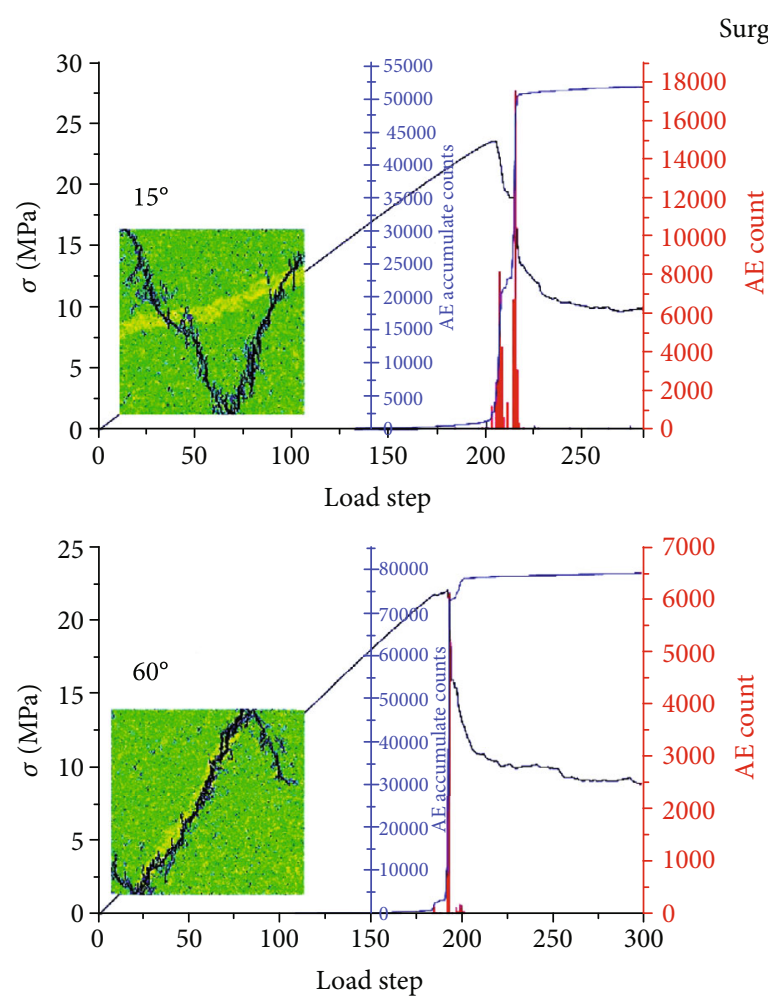

urge type

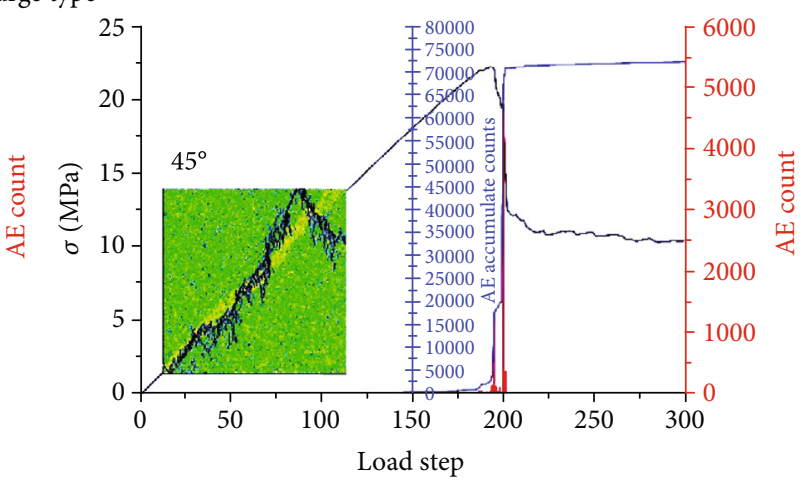

- $\stackrel{\sigma}{\text { AE counts }}$

- AE accumulated counts

(b)

FIgURE 14: AE evolution curves of the Niutitang Formation shale at different angles. 
characteristic of sudden energy release. In the initial stage of stress loading, the stress-strain curve is in the elastic stage, and almost no AE events occur. After reaching the yield stage, there are very few $\mathrm{AE}$ events in the crack initiation. With the increase of the load, when the stress approaches the peak intensity, the cracks rapidly expand to the specimen failure. The active period at this stage is short, the number of $\mathrm{AE}$ counts surges is small, the AE peak is large, and the failure mode is relatively simple

(10) Step type $\left(0^{\circ}, 30^{\circ}, 75^{\circ}, 90^{\circ}\right)$. In the previous description, the stress-strain curve of $\alpha=0^{\circ}, 30^{\circ}, 75^{\circ}$, and $90^{\circ}$ has many drops, showing the characteristic of gradual release of energy. In the initial stage of stress loading, the pores of the sample were compacted, and no acoustic emission signal appeared. As the load increased, the sample appeared initial cracks, and the acoustic emission signal appeared. When the stress is close to the peak stress, the initial crack grows to a sharp extension, and the acoustic emission shows a small and sharp increase for the first time. After the load increases to a certain value, the cracks extend sharply again or new cracks occur, and the acoustic emission again increases slightly and then reciprocates until a macrocrack is formed and the sample is broken. The active period at this stage is long, the number of AE count surges is more, the AE peak is small, and the failure mode is relatively complicated

In general, the evolution of the acoustic emission signals of the Niutitang Formation shale at different inclination angles is consistent with the failure process and failure mode.

\section{Conclusion}

(1) The inclination of calcite veins has significant influence on the anisotropy of mechanical properties of the Niutitang Formation shale. With the increase of the dip angle, the compressive strength and brittleness of the Niutitang Formation shale increases first, then decreases and then increases, reaching the maximum at $\alpha=15^{\circ}$, reaching the minimum at $\alpha=75^{\circ}$, showing N-type

(2) The inclination angle of the calcite vein affects the distribution of the stress field, leading to differences in the fracture process and fracture mode. According to their morphology, the failure modes of the Niutitang Formation shale under uniaxial compression can be divided into 4 types: w-type $\left(0^{\circ}, 30^{\circ}\right)$, v-type $\left(15^{\circ}\right)$, inverted v-type $\left(45^{\circ}, 60^{\circ}\right)$, and inverted z-type $\left(75^{\circ}, 90^{\circ}\right)$. According to the failure sequence of shale matrix and calcite vein, it can be divided into two types: the failure of calcite veins after the shale matrix $\left(0^{\circ}, 15^{\circ}, 30^{\circ}, 45^{\circ}\right)$ and the failure of the shale matrix after the calcite veins $\left(60^{\circ}, 75^{\circ}, 90^{\circ}\right)$
(3) During the microfracture of the Niutitang Formation shale with different calcite vein dip angles, the evolution of AE signals can be divided into 2 types according to the characteristics of the $\mathrm{AE}$ active period: surge type $\left(15^{\circ}, 45^{\circ}, 60^{\circ}\right)$ and step type $\left(0^{\circ}, 30^{\circ}, 75^{\circ}\right.$, $\left.90^{\circ}\right)$. The surge type has a short active period, a small number of AE counts surge, a large AE peak, and a relatively simple destruction mode. The step-type active period is long, the number of $\mathrm{AE}$ counts increases sharply, the AE peak is small, and the failure mode is relatively complicated

\section{Data Availability}

The basic data of this research is based on the results of physical experiments and previous research results. Z. Wu, Y. Zuo, S. Wang, T. Yi, and B. Li, "Numerical Simulation and Fractal Analysis of Mesoscopic Scale Failure in Shale Using Digital Images," Journal of Petroleum Science amp; Engineering, vol. 145, pp. 592-599, 2016. Y. Lou, et al., "Study on failure models and fractal characteristics of shale under seepage-stress coupling," Energy Science amp; Engineering, vol. 8, no. 5, 2020. Z. Wu, et al., "Acoustic and fractal analyses of the mechanical properties and fracture modes of bedding-containing shale under different seepage pressures," Energy Science amp; Engineering, vol. 8, no. 10, pp. 3638-3656, 2020, doi: http://doi.org/10.1002/ese3.772.

\section{Conflicts of Interest}

The authors declare that they have no conflicts of interest.

\section{Authors' Contributions}

Motian Tang contributed to the formal analysis, investigation, data curation, writing-original draft, and visualization. Zhonghu Wu contributed to the conceptualization, methodology, validation, and funding acquisition. Anli Wang contributed to the writing-review and editing and resources. Yujun Zuo contributed to the software, writing-review and editing, and funding acquisition. Yili Lou contributed to the writing-review and editing, supervision, and validation. Hao Liu contributed to the supervision, validation, and writing-review and editing. Jibin Sunwen contributed to the supervision, validation, and writing-review and editing.

\section{Acknowledgments}

This study was supported by the Project of Special Fund for Science and Technology of Water Resources Department of Guizhou Province (Project No. KT201804), the Guizhou Science and Technology Fund (Project No. [2020]4Y046, Project No. [2019]1075, Project No. [2018]1107), the National Natural Science Foundation of China (Project Nos. 51964007 and 51774101), and the Project: Scientific Research Project of Guiyang Rail Transit Line 2 Phase I Project (Project No. D2(I)- FW-YJ-2019-001-WT). This study is also funded by the Teaching reform project of Guizhou University (Project No. JG201990) and the Guizhou Province Graduate Research Fund (Project No. YJSCXJH[2020]086). 


\section{References}

[1] G. Pi, X. Dong, and J. Guo, "The development situation analysis and outlook of the Chinese shale gas industry," Energy Procedia, vol. 75, pp. 2671-2676, 2015.

[2] M. Mistré, M. Crénes, and M. Hafner, "Shale gas production costs: historical developments and outlook," Energy Strategy Reviews, vol. 20, pp. 20-25, 2018.

[3] Y. Chang, R. Huang, and E. Masanet, "The energy, water, and air pollution implications of tapping China's shale gas reserves," Resources, Conservation and Recycling, vol. 91, pp. 100-108, 2014.

[4] C. Wang, F. Wang, H. Du, and X. Zhang, "Is China really ready for shale gas revolution-re-evaluating shale gas challenges," Environmental Science and Policy, vol. 39, pp. 49-55, 2014.

[5] W. Yunna and Y. Yisheng, "The competition situation analysis of shale gas industry in China: applying Porter's five forces and scenario model," Renewable and Sustainable Energy Reviews, vol. 40, pp. 798-805, 2014.

[6] N. Vedachalam, S. Srinivasalu, G. Rajendran, G. A. Ramadass, and M. A. Atmanand, "Review of unconventional hydrocarbon resources in major energy consuming countries and efforts in realizing natural gas hydrates as a future source of energy," Journal of Natural Gas Science and Engineering, vol. 26, pp. 163-175, 2015.

[7] Z. Li, J. Zhang, D. Gong et al., "Gas-bearing property of the Lower Cambrian Niutitang Formation shale and its influencing factors: a case study from the Cengong block, northern Guizhou Province, South China," Marine and Petroleum Geology, vol. 120, p. 104556, 2020.

[8] W. Sun, Y. Zuo, Z. Wu et al., "Pore characteristics and evolution mechanism of shale in a complex tectonic area: case study of the Lower Cambrian Niutitang Formation in Northern Guizhou, Southwest China," Journal of Petroleum Science and Engineering, vol. 193, p. 107373, 2020.

[9] C. Wu, J. Tuo, L. Zhang et al., "Pore characteristics differences between clay-rich and clay-poor shales of the Lower Cambrian Niutitang Formation in the Northern Guizhou area, and insights into shale gas storage mechanisms," International Journal of Coal Geology, vol. 178, 2017.

[10] W. Sun, Y. Zuo, Z. Wu et al., "Fractal analysis of pores and the pore structure of the Lower Cambrian Niutitang shale in northern Guizhou province: investigations using NMR, SEM and image analyses," Marine and Petroleum Geology, vol. 99, pp. 416-428, 2019.

[11] Z. Yan, W. Qing, N. Zhengfu, and S. Hongliang, "A mathematical pressure transient analysis model for multiple fractured horizontal wells in shale gas reservoirs," Geofluids, vol. 2018, Article ID 8065949, 16 pages, 2018.

[12] H. Niandou, J. F. Shao, J. P. Henry, and D. Fourmaintraux, "Laboratory investigation of the mechanical behaviour of Tournemire shale," International Journal of Rock Mechanics \& Mining Sciences, vol. 34, no. 1, pp. 3-16, 1997.

[13] H. R. Wenk, M. Voltolini, H. Kern, T. Popp, and M. Mazurek, "Anisotropy in shale from Mont Terri," The Leading Edge, vol. 27, no. 6, pp. 742-748, 2008.

[14] J. Cheng, Z. Wan, Y. Zhang, W. Li, S. S. Peng, and P. Zhang, "Experimental study on anisotropic strength and deformation behavior of a coal measure shale under room dried and water saturated conditions," Shock and Vibration, vol. 2015, Article ID 290293, 13 pages, 2015.
[15] Z. Geng, M. Chen, Y. Jin et al., "Experimental study of brittleness anisotropy of shale in triaxial compression," Journal of Natural Gas Science and Engineering, vol. 36, pp. 510-518, 2016.

[16] Z. Wu, Y. Zuo, S. Wang, T. Yi, and B. Li, "Numerical simulation and fractal analysis of mesoscopic scale failure in shale using digital images," Journal of Petroleum Science \& Engineering, vol. 145, pp. 592-599, 2016.

[17] J. Wang, L. Xie, H. Xie et al., "Effect of layer orientation on acoustic emission characteristics of anisotropic shale in Brazilian tests," Journal of Natural Gas Science and Engineering, vol. 36, pp. 1120-1129, 2016.

[18] S. W. Zhang, X. F. Xian, J. P. Zhou, G. J. Liu, G. X. Jiang, and J. Y. Teng, "Acoustic emission characteristics and the energy distribution of the shale in Brazilian splitting testing," Jouranl of China Coal Society, vol. 42, Supplement 2, pp. 346-353, 2017.

[19] S. Heng, Y. Guo, C. Yang, J. J. K. Daemen, and Z. Li, "Experimental and theoretical study of the anisotropic properties of shale," International Journal of Rock Mechanics and Mining Sciences, vol. 74, 2015.

[20] P. Wang, F. Ren, S. Miao, M. Cai, and T. Yang, "Evaluation of the anisotropy and directionality of a jointed rock mass under numerical direct shear tests," Engineering Geology, vol. 225, pp. 29-41, 2017.

[21] X. Li, J. Zhang, Y. Wang, M. Guo, Z. Wang, and F. Wang, "Accumulation condition and favorable area evaluation of shale gas from the Niutitang Formation in northern Guizhou, South China," Journal of Natural Gas Geoscience, vol. 3, no. 1, pp. 1-10, 2018.

[22] Z. Wu, Y. Zuo, S. Wang et al., "Numerical study of multiperiod palaeotectonic stress fields in Lower Cambrian shale reservoirs and the prediction of fractures distribution: a case study of the Niutitang Formation in Feng'gang No. 3 block, South China," Marine and Petroleum Geology, vol. 80, pp. 369-381, 2017.

[23] C. Y. Lu, Y. J. Zuo, Z. H. Wu, and Y. F. Xu, "Research on characteristics of geological structure and farcture of shale reservoir in Guizhou Fenggang area," Coal Technology, vol. 35, no. 8, pp. 124-125, 2016.

[24] Y. Zhao, L. Zhang, W. Wang, Q. Liu, L. Tang, and G. Cheng, "Experimental study on shear behavior and a revised shear strength model for infilled rock joints," International Journal of Geomechanics, vol. 20, no. 9, p. 04020141, 2020.

[25] W. C. Zhu and C. A. Tang, "Micromechanical model for simulating the fracture process of rock," Rock Mechanics and Rock Engineering, vol. 37, no. 1, pp. 25-56, 2004.

[26] C. A. Tang and S. Tang, "Applications of rock failure process analysis (RFPA) method," Journal of Rock Mechanics and Geotechnical Engineering, vol. 3, no. 4, pp. 352-372, 2011.

[27] Q. L. Yu, P. G. Ranjith, H. Y. Liu et al., "A mesostructure-based damage model for thermal cracking analysis and application in granite at elevated temperatures," Rock Mechanics and Rock Engineering, vol. 48, no. 6, pp. 2263-2282, 2015.

[28] Z. Li, L. Li, B. Huang et al., "Numerical investigation on the propagation behavior of hydraulic fractures in shale reservoir based on the DIP technique," Journal of Petroleum Science and Engineering, vol. 154, pp. 302-314, 2017.

[29] Z. Wu, Y. Zuo, S. Wang, J. Sunwen, and L. Liu, "Experimental study on the stress sensitivity and influence factors of shale 
under varying stress," Shock and Vibration, vol. 2018, Article ID 3616942, 9 pages, 2018.

[30] A. Li, W. Ding, K. Jiu, Z. Wang, R. Wang, and J. He, "Investigation of the pore structures and fractal characteristics of marine shale reservoirs using NMR experiments and image analyses: a case study of the Lower Cambrian Niutitang Formation in northern Guizhou Province, South China," Marine and Petroleum Geology, vol. 89, pp. 530-540, 2018.

[31] Q. L. Yu, C. A. Tang, and S. B. Tang, "Digital Image Based Characterization Method of Rock's Heterogeneity and its Primary Application," Chinese Journal of Rock Mechanics and Engineering, no. 3, pp. 551-559, 2007.

[32] Y. Lou, Z. Wu, W. Sun et al., "Study on failure models and fractal characteristics of shale under seepage-stress coupling," Energy Science \& Engineering, vol. 8, no. 5, pp. 1634-1649, 2020.

[33] Z. Wu, Y. Lou, S. Yin et al., "Acoustic and fractal analyses of the mechanical properties and fracture modes of beddingcontaining shale under different seepage pressures," Energy Science \& Engineering, vol. 8, no. 10, pp. 3638-3656, 2020.

[34] Y. Wang, H. Zhang, H. Lin, Y. Zhao, and Y. Liu, "Fracture behaviour of central-flawed rock plate under uniaxial compression," Theoretical and Applied Fracture Mechanics, vol. 106, article 102503, 2020.

[35] J. Li, B. Yu, J. Zhang, Y. Li, and J. Wu, "Reservoir characteristics and their influence factors of the Lower Cambrian dark shale in northern Guizhou," Oil \& Gas Geology, vol. 33, no. 3, pp. 364-374, 2012.

[36] W. Gao, J. Iqbal, D. Xu, H. Sui, and R. Hu, "Effect of brittle mineral size on hydraulic fracture propagation in shale gas reservoir," Geofluids, vol. 2019, Article ID 9147048, 14 pages, 2019.

[37] R. M. Holt, I. Larsen, E. Fjær, and J. F. Stenebråten, “Comparing mechanical and ultrasonic behaviour of a brittle and a ductile shale: relevance to prediction of borehole stability and verification of shale barriers," Journal of Petroleum Science and Engineering, vol. 187, article 106746, 2020.

[38] G. Q. Chen, C. Zhao, T. Wei, and J. T. Wang, "Evaluation method of brittle characteristics of rock based on full stressstrain curve and crack initiation stress," Chinese Journal of Rock Mechanics and Engineering, vol. 37, no. 1, pp. 51-59, 2018.

[39] A. C. Eringen and B. S. Kim, "Stress concentration at the tip of crack," Mechanics Research Communications, vol. 1, no. 4, pp. 233-237, 1974.

[40] Y. Zhao, L. Zhang, J. Liao, W. Wang, Q. Liu, and L. Tang, "Experimental Study of Fracture Toughness and Subcritical Crack Growth of Three Rocks under Different Environments," International Journal of Geomechanics, vol. 20, no. 8, 2020.

[41] Y. Zhao, Y. Wang, W. Wang, L. Tang, Q. Liu, and G. Cheng, "Modeling of rheological fracture behavior of rock cracks subjected to hydraulic pressure and far field stresses," Theoretical and Applied Fracture Mechanics, vol. 101, pp. 59-66, 2019.

[42] H. Lin, H. Yang, Y. Wang, Y. Zhao, and R. Cao, "Determination of the stress field and crack initiation angle of an open flaw tip under uniaxial compression," Theoretical and Applied Fracture Mechanics, vol. 104, article 102358, 2019.

[43] D. Lockner, "The role of acoustic emission in the study of rock fracture," International Journal of Rock Mechanics and Mining Sciences \& Geomechanics Abstracts, vol. 30, no. 7, pp. 883-899, 1993.
[44] E. Eberhardt, D. Stead, B. Stimpson, and R. S. Read, "Identifying crack initiation and propagation thresholds in brittle rock," Canadian Geotechnical Journal, vol. 35, no. 2, pp. 222-233, 1998.

[45] W. C. Zhu, J. Liu, T. H. Yang, J. C. Sheng, and D. Elsworth, "Effects of local rock heterogeneities on the hydromechanics of fractured rocks using a digital-image-based technique," International Journal of Rock Mechanics and Mining Sciences, vol. 43, no. 8, pp. 1182-1199, 2006. 